\title{
From the Desk of the Honorary Secretary General
}

Dear Members,

You will be glad to learn that the Annual General Assembly 2015 of IIW-INDIA was held successfully on 25-26 September, 2015 at Hotel Golden Parkk, 13-Ho Chi Minh Sarani, Kolkata - 700071.

IIW-India's National Strategy on Accounting System with special emphasis on Implication of Income Tax was held on 25th September, 2015. A detailed guideline on the Accounting Systems and Procedures were presented by the Chairman, Finance Committee \& Accounts \& Service Manager, IIW-India. Most of the Branch Chairmen and Secretaries were present in the meeting and deliberated on the matters pertaining to Service Tax, Income Tax, TDS, utilisation of Fixed Deposits and General Accounting Policies for preparation of the accounts by branches of the Institute. Our Internal Auditor, Mr. Mahalnabish \& Mr. De, Representative of our Statutory Auditor took part in the discussions.

The proposed IIW-India Governance was presented by Mr. Parimal Biswas, Hony. Secretary General. The main purpose of this manual was to put all the activities of the Institute in one place, which will be the guideline to all. The same will be circulated to all Branches and Council Members for their comments / suggestions.

The Council decided to hold the Golden Jubilee Celebration of the Institute at the Science City Auditorium at Kolkata on the 22nd April, 2016.

The 6th IIW Welding Research Colloquium will be held on 7-9 April, 2016 at MAK Club \& Resorts, Hyderabad. This colloquium will be a three day fully residential programme.

The 49th Annual General Meeting of our Institute was held on 26th September, 2015 at 5:30 p.m. We must thank all the Branch Managing Committees for holding their AGMs within the stipulated time. Altogether 54 members attended the AGM. Mr. R. Srinivasan was re-nominated as the President of the Institute for the second consecutive year.

Further, it was felt that to provide wider scope of representations from the Industrial Corporate Members in the Council, two new Industrial Corporate Members viz. M/s. Bombardier Transportation of Gujarat and M/s. ADOR Fontech Ltd. of Bangalore were inducted in the Council.

The Council nominated Mr. D. S. Honavar for the "Life Time Achievement Award" and Dr. G. Madhusudhan Reddy as the speaker for the "Keith Hartley Memorial Lecture" for the year 2015. Hearty congratulations to Mr. D. S. Honavar and Dr. G. Madhusudhan Reddy for winning these awards. IIW-INDIA Baroda Branch was chosen as the winner of the "Minati Bhattacharya Memorial Award for Excellence" being the best performing Branch in 2014-15 for the third successive year.

On 21st September, 2015 a Workshop on IIW-INDIA MES activity took place at the Registered Office to discuss various issues and operational problems faced by the State Co-ordinators as well as the Authorised Assessors during assessments. A Technical Session was also conducted on Welding Technology. On 22nd September, 2015, the SDC assessors met at the IIW-INDIA Head Office to attend the Workshop on the recent developments on the assessment procedure under the PMKVY Scheme operated by IIW-INDIA's Skill Development Committee.

This year the National Welding Meet-2015 will be hosted by Cochin Branch at the Rajagiri School of Engineering and Technology, Rajagiri Valley, Kakkanadu, Cochin on the theme "GENERATION NEXT: ADVANCEMENT IN METAL JOINING" on the 9 th of October, 2015.

This year the National Welding Seminar -2015 will be hosted by Mumbai Branch at the CIDCO Exhibition Centre, Vashi, Navi Mumbai from 9 to 11 December, 2015 accompanied by the 10th edition of "WELD-INDIA", the International Welding Exhibition which will be organized in the same venue from 10 to 12 December, 2015.

All are requested to be present as delegate to the above program and extend their fullest cooperation to make these events successful.

The autumn festival has already been started. My best wishes to all of you on the eve of 'DUSSERA' \& 'DIWALI' .

Best Regards.

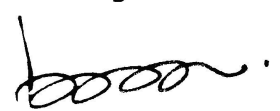

\section{Parimal Biswas}

M.No +91 9831052652

E-Mail Id : parimal.biswas@iiwindia.com 